\title{
As the Beat Goes on in Syria, is There an Exit Route?
}

\section{Osaretin Idahosa, PhD}

Department of Political Science, University of Benin, Benin City, Nigeria

\author{
Harrison C. Ajebon \\ Department of Political Science, \\ University of Calabar, Calabar, Nigeria
}

Doi: 10.1515/mjss-2017-0041

\section{Abstract}

The UN Security Council unanimous Resolution 2254 (2015) endorsed a Peace Process for Syria on December 18, 2015. By this token the global body called on President Bashar-al- Assad and opposition groups to sheath their swords and allow a political settlement in the country. In context of the dynamics of the Syrian conflicts, this study looks at the workability of the resolution meant to reduce the cost of the war and deterioration of humanitarian conditions. The study reveals that after over half a decade of brutal mutual carnage (by both government and opposition forces) a top-bottom imposed peace process has lost its appeal. Rather, a bottom-top remedy that uses the cultural assets of the Syrian people to create a movement for peace and reconciliation in the country is urgently needed.

Keywords: Syria, Global, Humanitarian, Opposition, Peace, Resolution, War

\section{Introduction}

Resolution 2254 (2015) adopted by the Security Council of the United Nations at its $7588^{\text {th }}$ meeting, on 18 December 2015 reaffirms the commitment of the global body to the sovereignty, independence, unity and territorial integrity of Syria. This resolution:

(expresses) its gravest concern at the continued suffering of the Syrian people, the dire and deteriorating humanitarian persistent and brutal violence, the negative impact of terrorism and violent extremist ideology in support of terrorism, the destabilizing effect of the crisis on the region and beyond, including the resulting increase in terrorists drawn to the fighting in Syria, the physical destruction in the country, and increasing sectarianism, and underscoring that the situation will continue to deteriorate in the absence of a political solution (United Nations, 2015:1).

The unanimity of the Security Council in approving the resolution referred to above for Syria demonstrated the determination of the global body to help end the war in the country. The singular act was a follow-up to the Vienna (Austria) peace process that called for a time-table for peace that would culminate in the creation of a unity government and elections in the country.

However, there are daunting obstacles to ending the six-year old civil war. These include the socio-economic cost of the collateral damage of the war, the division among the opposition and the future of Syrian President Bashar al-Assad. Also included are the differences among the various groups and their plans for a future Syria rebel. A major question that is raised by the adoption of Resolution 2254 is: will the resolution of the Syrian crisis be attained through the UN apparatus? 
Secondly, is there an alternative route to the resolution of the protracted crisis in Syria? The conflict in Syria has not only become a medium for states to exhibit their influence in international politics but has also drawn major powers, supporting and opposing the Assad Regime and the myriad of opposition groups against it.

\section{Theoretical Perspectives}

To fully understand the content and context of the crisis, a convergence of different theoretical perspectives needs to be explored. To the realists, interstates relations are often explained in context of power. According to Kissinger (1975) "power dictates how states interact with one another" and "because power relations are central to a realist understanding of the international arena", states are often skeptical to trust one another. As such, rather than trust, states choose their alliances based on one another's strategic value in the so-called 'self-interested'. This selfinterest could create a necessary condition for international conflict as different states interests could run at cross-purposes (Grovogui, 2002:14-25).

Frustration-Aggression Theory which has been widely employed in the study of both intrastate and inter-state conflict draws is strength from the fact that aggression is always a consequence of frustration (Dollard, Miller, et al., 1939). The central argument of the frustrationaggression theory is anchored on the fact that frustration begets aggression. Thus, the immediate response of an individual or group who is frustrated is to aggressively strike at the root-cause of the frustration. To this perspective, conflict becomes an aggressive action occasioned by frustration and the proponent is an individual whose goal in life is blocked by the social circumstances of society (Gurr, 1970).

Building on the foregoing premise, the Conflict Entrepreneurship Theory has equally been used to analyze conflict or violent situation beyond the causality of frustration and ideological differences. The theory posits that in every conflict or crisis situation, there are certain individuals (whether states or private persons) illegally benefiting from such uprising. These classes of actors, who indirectly fuel crisis for their private gains, are often referred to, as "conflict entrepreneurs" (Spencer, 2013). According to Weinberg (2014:54):

any conflict entrepreneur worthy of such label will mobilize his group for conflict by convincing the potential group members that the mobilization is for a collective good or in order to avoid the disastrous effects of the other groups mobilizing first.

Consequently, in many of the conflicts of global reach today, there are certain individuals and sate actors "that seek to increase their power", position "and wealth through participation in" these conflicts "by violent means". According to Spencer (2013), "it is interesting to note that in many countries, this can be an opportunity for an individual to make a career in term of power and wealth". Conflicts therefore can be seen as a means of gaining status, influence and wealth; thus the phrase "conflict as a career". This indeed, is a basic assumption of Entrepreneurship theory of conflict.

\section{Research Methodology}

This study adopts a historical methodology. This approach allows the authors to gather the required data through primary and secondary sources. Thus, speeches, articles, official pronouncements, communiqués, etcetera, formed a crucial part of the document analysis on the ongoing war in Syria. This archival and analytical review of extant literature allows for an understanding of the past, the present and the possible future dynamics of the Syrian crisis in a complex web of actors and interests.

\section{The Syrian Crisis in Brief}

Even before the crisis in 2011, there were ominous signs that Syria was susceptible to state 
fermentation. According to Slim and Trombetta (2014:1), "unsustainable authoritarian governance and economic decline were generating significant internal pressure across Syria's extremely localized society." This was accentuated by the fact that different local and sectarian alliances competed for relevance in the country's political space. This prognosis was symptomatic of the likelihood of a protracted and prolonged conflict with international dimensions, should any occur.

There are different schools of thought on how the Syrian crisis began. One of such holds that the unrest began after the state police arrested fifteen boys in Southern town of Daraa for spraypainting anti-government graffiti "the people want the downfall of the regime" on buildings on March $6^{\text {th }} 2011$ (Shanahan, 2013). Some of these boys were later killed in detention. An accompanying public protest erupted throughout the country which was given momentum by the failure of the Assad Regime to investigate and prosecute the offenders.

Another perspective believes that the Syrian crisis emerged in the wider context of the Arab Spring. Starting in Tunisia after the self-immolation of Mohammed Bouazizi in 2010, this wave of general discontentment against regimes in the sub-region grew in Syria out of anger over high unemployment rate, decades of repressive dictatorship, corruption and state violence (Manteda, 2014; Slim and Trombetta, 2014). The crises that began as peaceful mass protests for democracy against the 40 years regime of the Assad dynasty descended into a bloody crackdown before morphing into a bitter civil war.

As these protests spread from rural areas to urban centers, the crackdown from the Syrian government was swift. An angry response from government led to the death of four people on 18 March, 2011. This was closely followed by the Syrian Army firing at demonstrators in April of the same year (Shanahan, 2013). By July 2011, an organized rebellion against the Assad Regime was borne with the formation of the Free Syrian Army (FSA). The FSA is an umbrella body for a combination of different local area tribal groups, deserters from the Syrian military and disaffected local militias. Aside the fact that the Assad Regime refused to stop attacks on those opposed to his leadership, he did not implement meaningful reforms demanded by the protesters. Instead the regime abolished the martial law which was in place for decades and promised more reforms which would include new electoral laws, new media laws and a new constitution by February 2012 (Slim and Trombetta, 2014). Nonetheless, military and police repression continued and was complimented by the brutality of the Shabiha (a heavily armed state-sponsored militia). Although President Assad consistently denied responsibility for these atrocities, placing the blame for the violence on armed groups and terrorists (who correspondingly accused the Syrian Government of same); this mutual bulk passing has not been able to change the essential relationship between the regime and the Syrian people.

As the crisis continued to escalate, opponents of the Assad Regime formed the Syrian National Council (SNC) in August, 2011. Syrian opposition, including FSA, remains ideologically divided and fragmented as it remains only a factious collection of political groups, longtime exiles, grassroots organizers and armed militants whose operations are tainted by ethnic and/or sectarian identities. Also, the rivalry between various opposition outfits and the growing role of hard-line Islamist fighters provided enough fertile ground for an extremist group called Islamic State (IS) to take over large areas of the country.

Many Syrian citizens have been caught up in the cycle of violence during the war and have been forced to leave the country to escape to safety in other countries. Initially, these refugees fled across the Syrian borders into the neighboring states of Iraq, Jordan, Lebanon and Turkey. However, as the capacities of these countries were stretched to their limits, hundreds of thousands of them made their way to Europe. Estimates of deaths in the Syrian crisis vary. In August 2015, it was estimated that 250,000 people had died in the conflict (United Nations, 2015). Another report by the Economist (2016) showed in Figure 1 puts the death toll as at February, 2016 at 470,000. 


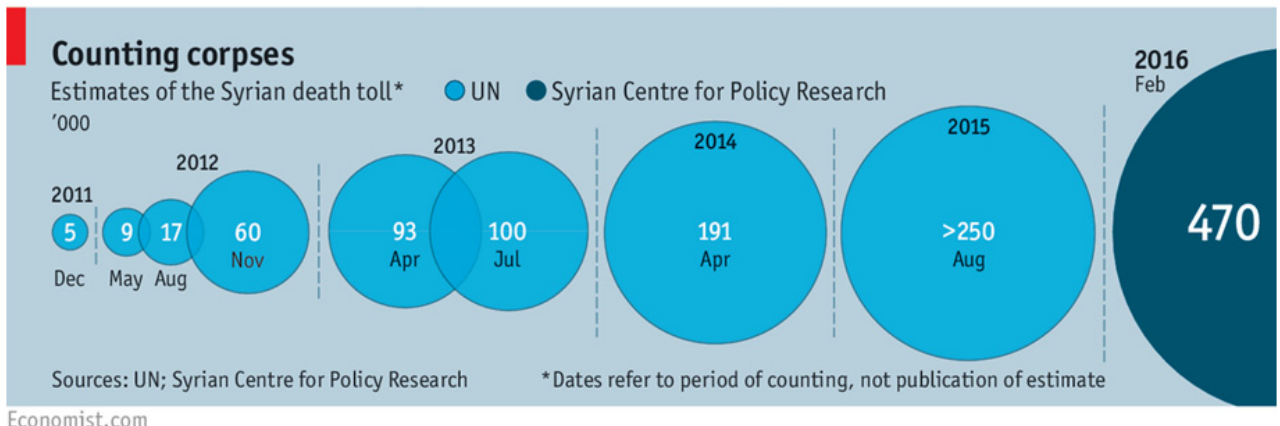

Figure 1:

Either way, the death toll has been very high. By July 2015 , there were at least $7,600,000$ Internally Displaced Persons in Syria (IDMC, 2015). Also, 3,975,842 refugees originated from the country as of April 2015 (UNHCR, 2015). The refugee crisis has taken its toll not only on Syria's neighbors, but as far as European countries. This has been manifested in the negative impacts it has had on the livelihood, public services and basic commodities of the local communities of the host nations. Thus, the mass migration of refugees to the epicenters of Europe (notably, Italy, Greece, France, Germany, Belgium, etc.), is worthy of note. In 2015, Germany alone received about I million refugees from the Middle East, most of whom were from Syria. Approximately the same number was expected for 2016 (UNHCR, 2015).

\section{External Involvement}

The Syrian civil war is wrought with numerous contributing factors with controversial implications. A variety of these factors can help explain what is happening in the country. The conflict is broadly divided between four main factors; (a) Al-Assad Regime, (b) Anti-Assad Opposition (c) The Kurdistan Workers Party (PKK) and (d) the so-called Islamic State (IS) or Da'esh as it is known in the Middle East. Each side has different foreign backers. Also regional powers have been involved in the conflict as early as late 2011; with Iran backing the Assad-Regime and the Gulf States backing the opposition through Turkey. Compounding this dire situation are the United States' and Russia's polarized responses to President Bashar Al-Assad and the disagreement over military strategies for toppling IS's stronghold in the sub-region. Although, the United States and Russia are rivals for regional interests, their interests are mostly aligned in terms of combating the Islamic State.

Domestically, the Assad Regime relies on State armed forces and pro-Regime paramilitary groups to fight the armed opposition forces. Syrian opposition groups have no unified command structure. These forces comprise a broad range of groups, from radicalized Islamic groups to leftwing secular parties and youth activist groups, who, though, agree on the need for Assad's departure, but share little common ground over how it should be implemented. The diffusive nature of its operation creates rivalry between different outfits within the ranks of the opposition thereby allowing hardliners to exploit this inadequacy. In the Middle East, Syria is strategically located. This importance enables both the Assad Regime and the opposition groups to draw up diplomatic and military support from various foreign sponsors. While the U.S. and most of Europe support the opposition groups, Russia, Iran and the Lebanese Shiite group Hezbollah are allies of the Assad Regime. Regional governments concerned about Iran's regional influence back the opposition; particularly Turkey, Qatar and Saudi Arabia.

The Syrian civil war which has been on for over six years is underpinned by a complex pattern of alliance and enmities. The Assad Regime and opposition groups are backed for different reasons by different countries. Table 1 is a summary of the alliance patterns of the war in Syria. 
Table 1: Foreign Alliances in Syria

\begin{tabular}{|l|l|l|l|}
\hline & Support & Type of support & At the UN security council \\
\hline United States & Syrian opposition. & Air strikes, Arms supply. & $\begin{array}{l}\text { Supports resolutions, critical } \\
\text { of Assad. }\end{array}$ \\
\hline Russia & Assad. & Air strikes, financial aid, Arms supply. & $\begin{array}{l}\text { llocked resolution, critical of } \\
\text { Assad. }\end{array}$ \\
\hline European Union & Syrian opposition. & Air strikes, Arms supply. & $\begin{array}{l}\text { Supports resolution, critical of } \\
\text { Assad. }\end{array}$ \\
\hline Turkey & Syrian opposition. & Arms supply, material assistance. & $\begin{array}{l}\text { Supports sanction against } \\
\text { Assad. }\end{array}$ \\
\hline Iran & Assad. & Material and financial assistance. & Supports Assad. \\
\hline Saudi Arabia & Syrian opposition. & Material and financial assistance. & Supports opposition. \\
\hline
\end{tabular}

Source: Author's Compilation, 2016.

The United States and Russia, the two main powers embroiled in Syria, remain on opposite sides. Since the end of the Cold War in 1991, the United States of America arguably remains the world's only superpower (a position Russia is not comfortable with). This privileged position guarantees the U.S. an unparalleled ability to exert its influence and project its power on a global scale (Bremer, 2015), though Huntington (1999) rejects this theory in favour of multi-polar balance of power. Since the end of the Cold War, Russia has tried to offer itself as an alternative model of influence and leadership on the international stage and in particular to regard itself as a key player in the Middle East. Thus, Russia has sought to parlay it Middle East connection into special relationship with both Iran and Syria. In contest of the Syrian crisis, the Assad Regime has so far gravitated towards Russian real politics as an alternative to its engagement with the United States. Russia clearly has an obsession with American hegemony, one that has taken on an added force during the current Syrian crisis. The Assad Regime suspects that an alliance between itself and Russia (a power with global reach) is little different from, and maybe more in its interest than, forgoing a partnership with the United States that constantly calls for its replacement.

Once the epicenter of the Islamic Caliphate, Syria has seen invasions and played host to occupations over the ages; from the Romans and Mongols through the Crusaders and the Turks. In the present dispensation, Syria is a turf for proxy wars between and amongst varied international actors whose interests are not beneficial to the country. Rather, these interests are driven by the individual and/or the collective interests of the participating countries.

Internally, Syria has undergone a rapid process of state ferment since the early days of the conflicts. Both the Assad Regime and opposition forces have contributed to the self-destruct of the country. Within the sub-region, the seeming asymmetrical interests of Turkey, Saudi Arabia and Qatar almost guaranteed that the political opposition in its various guises would reflect the competition between its external supporters. To Saudis, the desire to replace Shiite regime with Sunni Islam is one of the complications which deeply underpin its involvement. This is because the Assad Regime is majorly composed of Shiite Muslims while the Saudi Regime and most Saudis are Sunni Muslims. Turkey's involvement is bolstered by its sheer desire not to accept a Kurdish enclave on its southern border. Syria is a demographic mosaic of complicated ethnic and religious divisions. The country's 19 million people are divided into Sunni Arabs (65\%), Alawis (12\%), Christians (10\%), Kurds (9\%), Druze (3\%), Bedouin, Ismailis, Turcomans, Circissians and Assyrians (Potter, 2014). According to Kaplan, in Syria:

the sharpest divide may not so much be religion or ethnic as it is ideological and existential, pitting Muslims who want to align politics with religion against those who wish to keep them against those who wish to keep them apart (Kaplan, 2012).

However, both the Assad Regime and the opposition groups have accused each other of employing sectarian agitation. Despite the opposition groups' attempts to present a non-sectarian message while accusing the government of agitating sectarianism, the war in the country is rapidly 
devolving into an open sectarian and ethnic conflict. This has raised the ability to take the specter of reprisal killings and orchestrated violence to an unprecedented level. The sentiment in the West mirrors the skepticism about the Syrian opposition: to what degree secular liberal democracies should support groups that are neither secular nor liberal. Also, continuity of the President Assad in power presents challenges for the West. The fractured nature and predominance of radicalized Islamic groups of the armed opposition means that finding reliable allies whose values system are acceptable to Western values has been difficult. There is also the apprehension that whoever replaces President Assad might be less friendly to the West.

Furthermore, Shanahan (2013), argues that "the desire of the supporters (Russia and Iran) of the Assad Regime to maintain Syria within their geo-political orbit by ensuring as much of the regime as is feasible remains in place is a strong proposition". Russia, Iran, the Lebanese Shiite group Hezbollah and to a lesser extent Shiite dominated parts of Iraq are strong allies of the Assad Regime. For Iran which hosts more than $90 \%$ of Shiite Muslims, it only too natural to support the Assad Regime and its enemies in the country and elsewhere in the Middle East. Russia is an interested supporter of the government in Damascus because it has a base in the Syrian port to Tarsus, from where it is just over 1000 nautical miles to Russia's Black Sea naval bases (Sharwood, 2015). This is nonetheless, complemented by Russia's desire to re-invent its dwindling relevance in the Middle East and also stand up to the West.

\section{Making the Peace}

On $18^{\text {th }}$ December, 2015, the United Nations Security Council unanimously adopted a resolution calling for ceasefire and political settlement in Syria. While endorsing talks between the Syrian government and opposition, the resolution sought for a political solution to the Syrian crises. Accordingly:

the Security Council today endorsed a road map for a peace process in Syria, setting out an earlyJanuary timetable for United Nations-facilitated talks between the Government and opposition members, as well as the outlines of a nationwide ceasefire to begin as soon as the parties concerned had taken initial steps towards a political transition (United Nations, 2015:1).

Besides, the resolution also asked the United Nations Security Council to convene formal talks on a transitional government between the Assad Regime and opposition in 2016. This should be done to support a Syrian-led political process that would set up "inclusive and non-sectarian governance" (United Nations, 2015) within six months and schedule a process for drafting a new constitution, with the aim of holding free and fair elections in 18 months. There was much skepticism about the UN Resolution 2254 on Syria; agreement was rife that the UN unanimous vote was a crucial step forward, though the goal of "credible, inclusive and non-sectarian governance" (Al- jaafari, 2016) within six months was seen as hugely ambitious. While President Assad and his allies welcome the resolution referred to above because it did not exclude the Syrian leader from the peace process, the opposition and their allies will continue to see the non-exclusion of Assad as an issue that would block progress in the search for peace in the country.

Attempts by the United Nations to broker ceasefires and start dialogue on the Syrian crisis have failed in the past. One of such was the United Nation's convened conference in Switzerland in January 2014 to implement the 2012 Geneva Communiqué (BBC News, 2014). Unfortunately, the Geneva II broke down in February after only two rounds. UN- Arab League envoy Lakhdar Brahimi to the conference later blamed the failure on the Assad Regime's refusal to discuss opposition demands and its insistence on a focus on fighting "terrorist" (a term the Assad Regime uses to describe opposition groups) (Rodgers, Gritten, Offer and Asaire, 2015). Also, a stubborn gridlock in the United Nations Security Council majorly between the U.S. and Russia has long blocked any step towards a political resolution of the Syrian crisis. The U.S. and Russian approaches to dealing with the war in Syria are a study in contrast. Although differences still exist between the U.S. and Russia, the December 2015 resolution breaks new grounds not only in calling for a political solution to the conflict with a transitional government, but also in recognizing "ensuring continuity of 
government institutions" presently controlled by President Assad.

Paragraph two of the UN Resolution makes it clear that the negotiations are to be between "the representatives of the Syrian government and the opposition." This is not an easy proposition. Getting the Assad Regime representatives to future talks in Geneva might be easy (especially with the help of Russia), but the same cannot be said of the opposition Syrian National Council and their allies in the Middle East. Nevertheless, the general phobia is that nothing is new in the resolution, which stipulates elections under the UN supervision in eighteen months without the participation of President Assad. Even if pressure were to mount on President Assad to vacate office, his ruling Baathist party is highly unlikely to stay out of the transition process supported as it is by Russia and Iran (both determined to retain their influence in the sub-region). Russia's position is driven by a determined effort to prevent a repeat of the 'chaos' that followed the ousting of Saddam Hussein in Iraq in 2003 and Muammar Ghaddaffi in Libya in 2011, and underlined by the imperative to avoid such an outcome in the case of Syria.

The U.S. led Western Allies look at the Syrian conflict from three perspectives: (a) the security threat posed by the Islamic States, (b) the humanitarian crisis generated by the thousands of Syrian refugees in Europe and (c) the collateral damage from the war in Syria that has created a necessary condition for both internally and external migration of refugees. To this effect, Russia and Iran are often accused by the West of giving the Assad Regime maximum protection and support. Nonetheless, Russia in the past has vetoed United Nations Security Council Resolutions targeting the Syrian government (Soldatkin, 2016). Thus, the difference in perspectives by both U.S. led allies and the Russian led allies has over the years constituted a major obstacle to the UN Security Council's efforts towards a political resolution of Syria's devastating war. Though key actors and their supporters tended to believe there was no military solution to the crisis, not much has been achieved to secure the peace in the country. The United Nations' former envoy Kofi Annan bitterly blamed the world body when he quitted in 2012. According to him:

without serious, purposeful and united international pressure, including from the powers of the region, it is impossible for me, or anyone, to compel the Syrian government in the first place, and also the opposition, to take the steps necessary to begin a political process (Gladstone, 2012).

Moreover, prior to the voting, UN Special Envoy for Syria Staffan de Mistura underlined that there is no substitute to the political solution to the crisis in Syria (Al-jaafari, 2016). Thus, Members of the UN Security Council called on UN Secretary General and his Special Envoy for Syria to resume the Syrian-Syrian dialogue as soon as possible.

\section{Exit Route}

While the UN unanimous vote for the Syrian peace process was an important step forward, making the peace in the country has been a daunting task. Although supporters of the Assad Regime welcome the resolution that did not mention his role but for the opposition and their allies, the role or otherwise of President Assad in the peace process will continue to be the issue that could block the eventual fruition of the transition period. Equally important is the fact that groups seen as terrorist (including Islamic States and al-Nusra Front) are excluded from formal talks on a political transition in Syria.

Another sticking point in the peace process has been the branding of groups considered terrorist outfits and consequently excluded from the talks on Syria. The war in Syria pits the Assad Regime against many opposition groups with each trying to control territories. This position is further exacerbated by whether President Assad should be or not be included in the transition government. Keeping Assad in power will not help solve any of the problems associated with the crisis in Syria and excluding him will lead to a political deadlock.

An equally important fact is that the U.S. and Russian approaches to dealing with the Syrian crisis are somewhat asymmetrical. While the Obama Administration was indecisive in finding a political solution to the crisis, the Putin Administration did all it could to protect the Assad Regime (including aerial bombardment). As events unfold in Syrian, an extraordinary possibility has slowly 
emerged: the U.S. and Russia are fighting the Islamic State alongside each other. This fortuitous understanding could be explored as the basis for moving the peace process in Syrian forward. From this perspective, a genuine diplomatic initiative co-sponsored by both the U.S. and Russia that integrate key nations to the crisis in the sub-region might stand a chance of success.

Thus to solve the Syrian problem, local government officials, ethnic and religious leaders should be incorporated into the framework needed to broker a comprehensive agreement between the Assad Regime and opposition forces. This arrangement should be complemented by a wider effort by the United Nations. The local ownership of the peace process proposed here puts pay to the differences between the U.S. and Russian roles in Syria (which are more often than not divorced from the realities on the ground). What is needed in Syria is a comprehensive approach that integrates the interests of all the parties to the crisis in the beleaguered country.

Apart from the point noted above, creating an exit corridor for President Assad will be an added impetus to the peace process in Syria. President Assad should be made to sign a comprehensive peace agreement paving way for his eventual exit from power (Marwa, 2011). Just as the Yemeni parliament passed a law that granted Saleh immunity, from being prosecuted after office, President Assad should be assured same and be encouraged to leave the country to his preferred destination (probably Russia). The West and Russia should work towards realizing this objective.

Indeed, Saudi Arabia and Iran are two major sub-regional backers of the protagonists of the Syrian civil war. However, the energy dispensed by these two countries could be better channeled if pressure is put on both of them by the international community to sheath their swords and be integrated into the peace process. Here, the West must be ready to accommodate a moderated Iranian interest while Russia should do same to the interest of Saudi Arabia. The present practice of isolating Iran by the West is counter- productive to the whole peace process on Syria. Lessons should be drawn from the nuclear arm deals between the P-5 plus One and Iran and be replicated in the Syrian peace process. In fact, bridging the sectarian gap between the Iranians and Saudis will bring succour to the rather fractured relationship between the Shiites and Sunnis, not only in Syria, but also in the greater Middle East.

Paradoxically, in the context of the metamorphosis of the conflict, the Syrian opposition took distinct approaches to resist the Assad Regime. However, decentralization of the protest movement from the beginning of the conflict was meant to ensure the survival of the movement in the face of extreme repression by the Assad Regime. According to Slim and Trombetta (2014:22):

all leaders were aware of the constant risk of death or detention, and they knew it was essential to prioritize the continuity of the group after possible death or disappearance. The movement could not depend on a single person, which explains the absence of a clearly identifiable leadership on a national scale.

Thus, loose organizational structure of the opposition eventually played into the hands of the Islamist militant groups and foreign jihadist fighters who entered the country to reframe Syrian's political and economic conflict as a sectarian-oriented fight. The radicalization of the conflict has so far made it impossible to have a common front to engage the opposition groups. As peace remains elusive in Syria and the humanitarian crisis in the sub-region worsens, only an integrative approach to the peace process will suffice. Experience has shown that the current practice of isolating some opposition groups on the ground of their ideological orientations may never work. The management of such an initiative demands a complex mosaic of coordination and an all-inclusive team work that would guarantee a negotiated peace process that is accepted to all.

In the context of broader Arab solidarity, domestic ownership of the peace process should prevail. The process should be Syrian, supported by the Arab World and then, the International community. Negotiations should start from the local level, the national, the sub-regional and the international. This approach helps to solve the problem of selective isolationism as the different opposition groups excluded from the peace process would act as spoiler units to any transition process put in place. Also, it helps to resolve the dilemma built into the current practice of branding some opposition groups as terrorist organizations with whom the West cannot enter into direct 
talks. An improved local content in the peace process can remove the gridlock referred to above through a third-party negotiation. This gives to all the parties involved in the Syrian crisis a sense of ownership of the peace process. The implementation therefore will become binding on all the stakeholders in the Syrian project. The international community (especially the West and Russia) should know that no one understands Syria more than Syrian themselves. As such, externally crafted peace process, without full ownership by Syrians, amounts to a distortion of the historical evolution of the Syrian state.

\section{Conclusion}

Syria is a religiously mixed country on the throes of debilitating civil war. Efforts to end the war in Syria have been under intense global focus almost from the beginning of the crisis. The United Nations has tried to broker peace acceptable to both the Assad Regime and the opposition forces, with little or no success. The fundamental issues responsible for the paralysis of the international community efforts at making the peace in Syria are the disagreements between Western governments on one side, and Russia and China on the other, which has so far hindered any decisive action by the United Nations Security Council. This paper believes that after over six years of civil war in Syria, a top-bottom imposed peace process has lost its appeal. Rather, a bottom-top remedy is urgently needed. Therefore, there is the need for a grassroots movement that uses the cultural assets of the Syrian people to create a movement for peace and reconciliation in the country. This would stave off foreign governments who are interested only in their own strategic interests.

\section{References}

Al- jaafari, B. (2016). U.N. Security Council Adopts Resolution No. 2268 on Cessation of Combat Activities in Syria. Available at http://www.strianfreepress.wordpress.com. Accessed 27/02/2016.

BBC News, (2014). What is Geneva II Conference on Syria? 22 January, 2014. Available at http:// www.bbc.com/ news/ world-middle-east-246284. Accessed 23/07/2016.

Bremer, I. (2015). These are the Reasons Why the U.S. Remains the World's Only Superpower. Time. Available at http://time.com/3899972/us-superpower-status-military. Accessed 07/01/2015.

Dollard, J, Miller, N. E., et al. (1939). Frustration Aggression Theory. London: Yale University Press.

Gladstone, R. (2012) Resigning as Envoy to Syria, Annan Casts Wide Blame. The New York Times. Available at http://www.nytimes.com . Accessed 09/04/2016.

Grovogui, S.N. (2002). Regimes of Sovereignty: International Morality and the African Condition. European Journal of International Relations, 8(31): 14-25.

Gurr, T.R. (1970). Why Men Rebel. Princeton, New Jersey: Princeton University Press.

Huntington, S.P. (1999). The Lonely Superpowers. Foreign Affairs: 78(2).

IDMC (2015). Displacement in Syria as of July 2015. Available at http://www.internal-displacement.org. Accessed 07/01/2016.

Kaplan, S. (2012). Syria's Ethnic and Religious Divisions. Available at http://www.fragilestate.org. Accessed $17 / 01 / 2017$.

Kissinger, H. (1957). Strategy and Organization. Foreign Affairs: 35( 3).

Manfreda, P. (2014). Syrian Civil War Explained: The Fight for the Middle East. About News. Available at $\mathrm{http}: / /$ middleeast.about.com/od/syria/tp/Syrian-Civil-War-Explained.htm Accessed 04/01/2016. Accessed 26/06/2016.

Marwa, R. (2011). Yemen's Sleh Signs Deal to Give up Power. REUTERS World News, November 22, 2011. Available at http:// www.reuters.com/article/us-yemen-idUSTRE7A. Accessed 15/04/2016.

Potter, L. G. (2014). Sectarian Politics in the Persian Gulf. New York: Oxford University Press.

Rodgers, L., Gritten, D., Offer, J. and Asare, P. (2015). Syrian: The story of the Conflict. BBC News Online. Available at http://sa.bbc.co.uk/bbc/bbc/s? Accessed 24/09/2015.

Sharnahan, R. (2013). 10 Simple Points to Help You Understand the Syrian Conflict. Available at http://ww.news.com.au. Accessed 04/01/2016.

Sharwood, A. (2015). Syria Explained in 10 Simple Points: A Western Perspective on the Crisis. Available at http://www.news.com.au. Accessed 10/12/2015.

Slim, H., and Trombetta, L. (2014). Syria Crisis Common Context Analysis. Report Commissioned by IASC Inter-Agency Humanitarian Evaluations Steering Group as Part of the Syria Coordinated Accountability 
and Lessons Learning Initiative. United Nations Office for the Coordination of Humanitarian Affairs, New York, United Nations Headquarters, NY10017. Available at https://interagencystandingcommittee.org. Accessed 10/11/2015.

Soldatkin, V. (2016). Putin Names United States Among Threats in New Russian Security Strategy. REUTER. Available at http://www. Accessed 17/03/2015.

Spencer, A. (2003). Questioning the Concept of New Terrorism, Conflict and Development. Peace, conflict, \& Development, (8) : 1-33.

The Economist (2016) Quantifying Carnage: How Many People Has Syria's Civil War Killed? Available at http://www.economist.com. Accessed 09/04/2016.

UNHCR (2015). 2015 UNHCR Country Operations Profile Syrian Arab Republic. Available at http://www.unhcr.org/pages/49e486a76.html. Accessed 24/08/2015.

United Nations (2015). Alarmed by Continuing Syria Crisis: Security Council Affirms its Support for Special Envoy's Approach in Moving Political Solution Forward. Available at https://www.un.org/press/en/2015/sc12008.doc.htm Accessed 09/01/2016.

United Nations (2015). Security Council Resolution 2254 (2015) Adopted by the Security Council at its $7588^{\text {th }}$ Meeting on 18 December 2015. S/RES/2254. Available at www.un.org/press/en/2015/sc12171.doc.htm. Accessed 04/07/2016. 